\title{
Landscapes without the car: a counterfactual historical geography of twentieth-century Britain
}

\author{
Colin G Pooley \\ Lancaster Environment Centre, \\ Lancaster University, Lancaster, LA1 4YQ \\ c.pooley@lancaster.ac.uk
}

Tel: 01524510241

Fax: 01524510269

\section{Acknowledgements}

This paper benefited from comments made by participants at a session in the RGS conference 2006, a workshop in London in 2007 and three anonymous referees. In part, the paper draws on material collected in Lancaster-based research projects funded by The Leverhulme Trust (1996-99) and the ESRC (2000-2004). Particular thanks to Jean Turnbull and Mags Adams who worked as Research Associates on these projects. Thanks also to Simon Chew (cartographic unit, Lancaster Environment Centre) who drew the maps 


\begin{abstract}
Despite increased concern about environmental damage and resource depletion, the private motor car, and associated automobility, are taken-for-granted aspects of $21^{\text {st }}$ century life. This paper makes the counterfactual assumption that private ownership of cars was severely restricted at the start of the twentieth century, and uses a range of historical data to examine the ways in which such a scenario might have impacted on transport infrastructure, personal mobility and urban life. It is argued that, even without the wholesale adoption of the motor car as a means of personal transport, patterns of everyday mobility would not have differed significantly from today so long as other forms of transport had remained or expanded to cope with this demand. However, such a scenario would probably have required journeys to be planned in different ways, may have been qualitatively different from travel today, and could have disadvantaged particular groups of the population, including some women. A landscape without cars would probably also have altered the form of cities, with services provided closer to where people live, and levels of air pollution substantially lower. The counterfactual historical analysis is used to argue that, although there is little likelihood of cars being banned in Britain, greater restrictions on private motor vehicles would not necessarily lead to the fundamental changes in everyday mobility that some might predict.
\end{abstract}

Key words: Motor car; automobility; transport; mobility; urban form; environment Short title: Landscapes without the car Word count: 9,474 (excluding title, acknowledgements, abstract and biographical note); 7,534 excluding footnotes 


\section{Biographical notes:}

My research has focused on the social geography of Britain and continental Europe over the past 200 years, especially aspects of migration, mobility, health, ethnicity, housing, crime and social change. I am interested in how and why societies change, and the implications that past processes have for current policies. 


\section{Introduction}

The motor car is a taken-for-granted aspect of $21^{\text {st }}$ century life and most people in the developed world, at least, view it as essential to their everyday travel. Although there is increasing recognition of the environmental and congestion problems created by car use, ${ }^{1}$ all transport policy in Britain assumes that access to a car is the norm for most people and that intervention and regulation should do little more than mediate its impacts. ${ }^{2}$ This is reflected in the number of currently-licensed vehicles (approximately 34 million licensed vehicles and 43 million licensed drivers) in the $\mathrm{UK}^{3}$ and since the inception of vehicle licensing in Britain in 1903 there has been a steady year-on-year increase in the number of newly-registered vehicles ${ }^{4}$. It can be argued that although in 1956 there were still only 6.3 million licensed vehicles in the UK, from at least the mid twentieth century the motor car has had a major impact on the British landscape, economy and culture. Indeed, it has been argued that ever since the invention of the internal combustion engine there has been a form of 'path dependency' that has led to the almost inevitable domination of modern transport by the motor car, and by the business interests that promote it, to create present-day cultures of automobility ${ }^{5}$

But imagine a different scenario. Following development of the internal combustion engine and its application to moving vehicles in the 1870s, and the steady growth of motor vehicles in Britain to the first decade of the twentieth century (there were 17,000 licensed motor vehicles in the UK in 1903), let us assume that in about 1910 a decision was taken by government in Britain to prohibit the private ownership of motor vehicles. The technical development of engines and vehicles would have continued, but was 
applied to public transport, emergency vehicles, a limited number of registered delivery vehicles, licensed taxis and a small number of vehicles owned by elite individuals who would have been driven by strictly-regulated professional drivers. The roads of Britain would thus have been largely free of motor traffic, and private ownership of a motor vehicle would not have been an option for most people in Britain. This paper takes this starting point, and examines the ways in which some aspects of British landscape, economy and society might have developed differently if the private motor vehicle had been largely absent. Many themes could be explored, but attention is focused on three key areas: first, development of the transport infrastructure in Britain; second, patterns of individual mobility; and third the nature of urban life encompassing changes in aspects of urban structure, health and the environment. Where possible evidence to back up the assumptions made and scenarios built is drawn from historical research on travel and transport in Britain, especially the author's own research on everyday mobility in the twentieth century. ${ }^{6}$

The research that is used to substantiate arguments made in this paper was not originally intended for counterfactual purposes. The data seek to chart changes in everyday mobility in Britain over the twentieth century, and have been used to provide historical context to contemporary debates about mobility change. ${ }^{7}$ However, in thinking about the links between the past and the present, it became increasingly obvious that if an understanding of past mobility was used to construct a counterfactual argument about mobility change in Britain, then this may also contribute to contemporary debates about sustainable transport futures in the UK. Thus, the paper attempts to use a counterfactual analysis of 
historical evidence to construct an argument that is relevant to contemporary transport policy.

\section{Plausible Worlds}

Counterfactual histories are contentious and the arguments for and against their use are well rehearsed ${ }^{8}$. These are not repeated in this paper. Attempts at counterfactual analysis most often focus on military or political history ${ }^{9}$ with fewer attempts at counterfactual social, economic or cultural history ${ }^{10}$. This paper adds to the latter canon of work, though this is not without difficulty. Whereas most counterfactuals focus on a single event such as the outcome of an election or battle (which have a limited range of implications), counterfactuals of socio-cultural change necessarily embrace many different parameters and may have complex and multiple outcomes. ${ }^{11}$ Such complexity increases the uncertainty of any predictions. Perhaps the most important starting point for any counterfactual analysis is to pose the question: could the alternative scenario actually have happened? Or to put it another way, is the analysis an exercise in imagination that is devoid of reality, or does it provide a plausible alternative path that might in different circumstances have been taken? In the context of this paper the key question to pose is whether private motor vehicles could have been banned in Britain in the early twentieth century? This question can be approached from a number of different perspectives.

There was undoubted concern in late nineteenth-century Britain about the introduction of self-propelled traffic onto the roads. ${ }^{12}$ The first Locomotive Act of 1861 specified that 'locomotives not drawing a carriage should have the tires of their wheels not less than 
3in wide. They were to consume their own smoke, to have two drivers, the speed would not exceed 10 miles an hour, and all rights of treating them as nuisance were carefully preserved'. ${ }^{13}$ In 1863 the number of persons required to manage locomotives was increased to three (with vehicles preceded by a pedestrian with a red flag) and the speed limit was reduced to four miles an hour (two mph in cities, towns and villages). ${ }^{14}$ It was argued at the time that these restrictions severely curtailed the development of the light road locomotive industry in Britain. ${ }^{15}$ Following a Parliamentary enquiry and effective lobbying from automobile enthusiasts, in 1896 the speed limit was raised to $12 \mathrm{mph}$ and again to $20 \mathrm{mph}$ in 1903 . However, sensitivity about the impact of self-propelled locomotives on the roads continued as motor enthusiasts carefully stressed the lawabiding and safe nature of their passion. Thus in 1900 the Automobile Club of Great Britain organised a '1000 mile trial of motor vehicles' in part to overcome the views of those who 'think that no advantage is to be gained by further progress in the use of motor vehicles in England'. ${ }^{16}$ Over 80 vehicles took part in the eleven-day 'trial' which included gruelling hill climb sections and which passed through many of the major population centres of Britain, with exhibitions of cars in each of the towns visited. The organisers stressed that 'every possible precaution has been taken by the club in framing the rules to prevent the trial from being a source of danger and annoyance to the public. It must be clearly understood that the trial is a test of endurance, not a race. Hence the judges ... will not have regard to any record in excess of the legal limit of speed. The speed in passing through towns and villages is to be strictly limited to eight miles an hour. Of the any possible infringements of the rules which render competitors liable to the disqualification of their vehicles, that of failing to show consideration to the drivers 
of restless horses, is one of those upon which most stress is laid' ${ }^{17}$ It can thus be argued that if the pro-car lobby had been less successful, much stricter conditions could have been imposed on road traffic in Britain.

In fact, regulation in the twentieth century has been minimal. The 1903 Motor Car Act required all cars to be registered with the county or borough council in which the driver was resident, and for the registration number to be displayed; drivers of motor vehicles must have a licence (given by the local council for the payment of five shillings), but there was no test of driver competence though a new crime of 'reckless driving' was introduced to the statute books. ${ }^{18}$ In 1930 all speed limits for vehicles carrying less than seven people were abolished but, following increased concern about rising road casualties, in 1934 a 30 mph speed limit was introduced in built-up areas. However, other roads had no speed limit until 1965 when a national upper limit of $70 \mathrm{mph}$ was introduced for all roads (reduced to $60 \mathrm{mph}$ on single carriageways in 1977). ${ }^{19}$ The 1935 Motor Vehicles Regulation Act introduced a driving competency test for all individuals who began driving after $1^{\text {st }}$ Aril 1934 (suspended 1939-46 and again in 1956 during the Suez crisis) and in 1965 the DVLC was established to provide a national system of licensing vehicles and drivers. Seat belts became compulsory from January 1983, but in most other respects the private motorist remained relatively unregulated. ${ }^{20}$

Debates about road safety and the impact of motor vehicles on the roads were reasonably prominent, both nationally and locally, in the 1930s; but they often focused as much on improving the roads for car use and on reducing congestion as on issues of safety and 
regulation. ${ }^{21}$ For instance, in 1929 the Royal Commission on Transport heard evidence from municipal and county engineers about the need for road widening to accommodate vehicles (suggesting a minimum width of $30 \mathrm{ft}$ ) and also the view that 'too many speed limits reduced the effectiveness of the roads. The speed limits imposed in small towns and villages in the early days of motor regulations now had the effect of congesting large quantities of traffic. ${ }^{22}$ There was recognition of the need to manage traffic more effectively in towns (with traffic lights introduced in most cities in the 1930s) while a study of 1933 painted a somewhat futuristic vision of urban traffic regulation that in many respects is only being implemented in the $21^{\text {st }}$ century. Henry Watson argued that 'In future the central areas of great cities will be closed to private vehicles of limited utility, as they are partly closed by parking restrictions today. Traffic signs and signals will be of increasing complexity. Traffic movements will be watched from headquarters by automatic vehicle counters, television and auto-gyros, and locally from roof-high control bridges spanning the streets, whilst constables will receive their instructions through portable radio sets' ${ }^{23}$

Road casualties emerged as a national issue in 1934 when the Minister of Transport, Oliver Stanley, introduced a new road safety campaign with a national radio broadcast on the eve of the Easter holidays. He predicted 100 road fatalities over the Easter weekend and pleaded for care and responsible behaviour by all road users, whilst stressing that the motor car was very much a permanent fixture of Britain's roads and that responsibility for road safety lay primarily with road users rather than through regulation (whilst implying that regulation may have been possible in the past): 'Only the co-operation of 
every user of the road-motorist, cyclist and pedestrian - only their caution, their care and their courtesy could make the roads really safe. It was no good arguing which had the better right to the roads - motorists or pedestrians. They were both on the roads and they were going to stay there. Years ago when motoring was the privilege of the peer or the plutocrat, it might have been possible to resist what was only the luxury of the few. But today the luxury of the few had become the necessity of the many'. ${ }^{24}$ Although today Britain has some of the lowest road casualty figures in Europe, and rates are continuing to fall, none-the-less on average some eight or nine people per day are killed on the roads, with over 87 per day killed or seriously injured. ${ }^{25}$ Moreover, while improvements in vehicle safety have increasingly insulated the motorist, casualties have fallen disproportionately on pedestrians, cyclists and motor cyclists. It can be argued that if an annual death toll of some 3000 fit and healthy people occurred due to any other cause there would be a public outcry, with vehement calls for regulation. ${ }^{26}$ For instance, if a new and widely used life-style drug was found to kill 3000 users a year it would almost certainly be immediately banned. The fact that this annual death toll passes almost unnoticed demonstrates the power that the motor industry has achieved, and the degree of car dependency in modern society. ${ }^{27}$ However, from another perspective, if in 1900 it had been predicted that over half a million people ${ }^{28}$ would be killed on Britain's roads over the next century, then perhaps motor vehicles would have been more strongly regulated, even to the extent of banning most private cars. 


\section{Transport Infrastructure}

All transport depends on the development of an appropriate infrastructure, and one of the main impacts of car use on the British landscape has been the development of the facilities that support motoring: not only the road network itself but the signs and signals used to direct and control traffic, the petrol stations needed for refuelling vehicles and the service areas required to refresh motorists. ${ }^{29}$ In what ways would Britain's transport infrastructure have been different if the private motor vehicle had been severely restricted? Attention is focused on three aspects: the development of the motorway and trunk road network in Britain; competition for road space between cars and other road users in cites; and the impact of the motor vehicle on the British rail network.

By the 1930s, with some three million licensed drivers in Britain, there was increasing pressure to improve the trunk road network to enable cars to travel quickly and easily over long distances, avoiding congestion in major urban areas. ${ }^{30}$ Thus in 1936 the Institute of Highway Engineers published a plan for a network of motorways covering the entire country (from Dover to Glasgow and from Plymouth to Edinburgh): a network rather more dense than that actually achieved by the $21^{\text {st }}$ century (Figure 1a), and in 1938 the County Surveyors' Society published plans for a more skeletal network of 1000 miles

of motorway (Figure 1b). ${ }^{31}$ The urban and industrial region of north-west England provides a case study of the early evolution of motorways and improved trunk roads. One of the key issues debated in the 1930s, and still relevant today, was the degree to which new roads should be mixed use with frequent and easy access, or the extent to which new roads should be dedicated only to high-speed motor vehicles with limited access from 
other routes. Lancashire County Council proposed improving the N-S route of the A6/A49 with a high standard dual carriageway to include cycle tracks and footpaths throughout its length. However, the county council was also becoming increasingly concerned about the high accident rate that occurred on the new all-purpose LiverpoolEast Lancashire road that had been opened in 1934: this was ascribed to the mixed-use nature of the road and the frequent entry and exit points. Thus in 1937 the county council abandoned ideas for the A6/A49 improvement and instead proposed an entirely new N-S route with controlled access and restricted to motor traffic, in other words a motorway. A further influence on this move towards purpose-built high-speed roads restricted to motor vehicles (rather than mixed use routes) was the development of the German autobahn network; in 1937 a delegation of 224 British MPs, highway engineers and others inspected the German system. ${ }^{32}$ The impact of such visits also had local implications: for instance the municipal surveyor for Blackpool (a member of the delegation) argued that a proposed ring road for the town should be built as a motorway. The Minister of Transport, Leslie Burgin, approved Lancashire's proposals for a new 62 mile N-S route and preliminary survey work was undertaken in the late 1930s. Most work on new road infrastructure halted during the war, but in 1946 a new national road construction programme included both the N-S Lancashire route and an E-W Liverpool-ManchesterYorkshire route, and these were included in the 1947 Lancashire County Road Plan. The first section of the N-S route (the Preston bypass) was opened in December 1958 (the first stretch of motorway in the country) with the rest of the M6 through Lancashire built in stages and completed in $1965 .^{33}$ 
In the 1930s there was massive pressure for new road building dedicated to the motorcar, and the growth of motor traffic was a major factor in providing the infrastructure of motorways that eventually emerged in Britain. However, in some ways it is remarkable how slowly the motorway network evolved (with the network still rather less than that proposed in 1936). Never-the-less, it is clear that the private motor vehicle largely shaped the nature and development of new road building for much of the twentieth century. ${ }^{34}$ If access to private motor vehicles had been restricted the road network today would clearly look very different, and there would almost certainly be no motorways. However, there would still have been pressures for road improvement. It is reasonable to assume that buses (together with trains - see below - and possibly other more innovative forms of public transport) would have been used extensively for travel between and within urban areas, and there would be the need to accommodate delivery vehicles in areas not accessible by rail, and also emergency and other licensed vehicles. It seems likely that with respect to infrastructure, while the motorway network in Britain would probably not exist in a landscape without cars, there would have been substantial improvement of mixed use roads to accommodate buses, essential vehicles, cycles, and pedestrians. Perhaps Lancashire County Council's original proposals for an improved mixed-used A6/A49 would have gone ahead, but there would have been much less need to by-pass towns and, instead, it can be suggested that the major focus of road building and traffic management would have been on linking settlements effectively for a variety of road users, rather than on allowing one group (the motorist) to travel rapidly over long distances avoiding urban centres. 
Competition for road space between different forms of transport is especially acute within urban areas where, despite the development of some urban motorways, it is much more difficult to segregate traffic. How would traffic management in large cities have been different if access to private motor transport had been severely restricted? Again, it can be argued that the period between the two World Wars was a key era of change. In terms of road construction, many of the debates rehearsed above with regard to the trunk road system were replicated in and around large urban areas. London provides the best example. As early as 1905 the Royal Commission on London Traffic recommended the development of a circular road around London (roughly the route of the North and South Circular roads) but, due to the disaggregated nature of responsibility for transport planning in London at this time, progress was slow with only short sections completed and linked in a somewhat haphazard fashion. However, by the 1930s a more-or-less complete inner orbital route had been established. In 1934 the Minister of Transport (Leslie Hore-Belisha) initiated a survey of traffic and highway developments in London and in 1937 Charles Bressey and Edward Lutyens produced their Highways Development Survey. A key element of this was a proposal for an outer orbital road which, in part at least, became the M25 in the 1970s. ${ }^{35}$ As with the national motorway network, major new road building in London was undoubtedly stimulated by the motorcar but, in some respects, came remarkably slowly given the concerns generated in the early twentieth century.

Given the slow pace of new road construction, it is not surprising that much debate in the inter-war period focused on how the existing road network could be better used by the 
traffic of the time and, in particular, with competition between motor vehicles and other road users. Such issues came to the fore in Manchester in the 1920s and '30s. In the 1920s the tram network was the dominant form of public transport in the city and most people, including many car owners, regularly used trams for their everyday travel. Thus in 1926 the Manchester tram network recorded some 318 million passenger journeys. ${ }^{36}$ However, as in other cities the tram network attracted substantial criticism: it was seen as old fashioned and inappropriate for a modern city, with motor vehicles hailed as the symbol of progressive modernity. Trams were accused of being inflexible and of causing congestion by impeding other road users (especially motor vehicles); they were also regarded as expensive in that the travelling public had come to expect low tram fares but it was assumed they would pay more to travel on new motor buses. ${ }^{37}$ Thus, in the 1930 s, motor buses increasingly replaced trams as public transport in Manchester, and those who could afford to switched to the use of private motor transport, often stimulated by the argument that public transport had become less convenient or more expensive. Although there were some attempts to regulate cars in the 1930s (for instance Manchester introduced its first one-way system in 1936) the private motor car progressively came to dominate urban road space.

Would any of this have been different if the ownership of private vehicles had been restricted? Obviously urban traffic congestion would have been less and the demand for public transport (and possibly the use of cycles and walking for everyday transport) greater, but competition between trams and motor buses would have been much the same. Arguments against trams and in favour of motor buses were so strong that it can be 
suggested that the tram network would have disappeared from British cities regardless of the presence of private motorists, and in most cities trams had all but disappeared before mass car use developed. However, it can be argued that if private motor transport had not been available, the decline in the use of urban public transport that occurred in most cities from the 1960s would not have taken place, bus provision would have remained high, and that reinvestment in trams may have occurred earlier. These trends are all evident in London following the introduction of congestion charging, ${ }^{38}$ and it is reasonable to suppose that townscapes of the late twentieth century would have been dominated by motor buses, trams, cycles and pedestrians. Although congestion would undoubtedly still have occurred, it is likely that road space would have been more evenly allocated between different road users.

Prior to the expansion of the private motor vehicle, most people made long-distance trips by train. Many of course still do, but over the twentieth century the British rail system shrank from a dense network that penetrated most parts of the country to a more skeletal system primarily serving major cities and suburban commuters (especially in the SE) (Figures $2 \mathrm{a}$ and $2 \mathrm{~b}$ ). The crucial period for the decline of the railway network was the 1960s when the 1963 'Beeching Report' on the 'reshaping of British railways' argued that in many parts of the country railway provision was now not viable, and could not compete with growing car use. This led to the closure of some 5000 miles of track and the loss of 2000 stations. ${ }^{39}$ Many rural areas were left without ready access to the rail network. If car ownership had been restricted it is reasonable to assume that the Beeching cuts would have been less severe (focused on over-supply of competing routes rather 
than removing links from the network), that demand for rail travel even in rural areas would have remained high, and that the dense railway network of 1900 would have been maintained, or even extended, for both passenger and freight traffic. ${ }^{40}$ This is one way in which the landscape of Britain would have been very different, with arguably much greater investment than has occurred so far in high speed trains and new roiling stock. ${ }^{41}$ In this sense the rail network of c1900 (Figure 2a) can be viewed as a counterfactual map of the British rail network in the $21^{\text {st }}$ century if the scenario outlined at the start of this paper had taken place.

\section{Personal mobility}

Given the transport infrastructure scenario outlined above, what difference might the lack of access to private motor vehicles have made to personal mobility? It is argued that two key points are crucial. First, many people travelled freely over long distances before the development of mass car ownership, and a significant minority of people today choose not to own a car and manage to travel easily over long distances despite the denuded British transport system. Second, most everyday travel undertaken by individuals in Britain is over a relatively short distance, often less than two km, and for such trips other forms of transport can readily be substituted for the motor car (indeed, a car may not be the quickest or most effective means of transport for many such journeys in large urban areas). Thus it is argued that, assuming the maintenance of a high quality and dense public transport network, restricted car access would have had only a limited impact on personal mobility over the twentieth century. Evidence to support these assertions is 
drawn from recent research on everyday mobility in Britain over the twentieth century (Pooley, Turnbull and Adams 2005), with only the briefest summary presented here. ${ }^{42}$

There have been significant changes in the journey to work in Britain over the twentieth century, with the mean distance travelled to work (males and females) increasing from around $4 \mathrm{~km}$ in 1900 (with about half of all trips on foot) to just under $15 \mathrm{~km}$ in the 1990s (with fewer than ten per cent of trips on foot and 50 per cent by car). However, the time spent travelling to work has increased much less. By the 1920s the mean time taken to travel to work was 30 minutes and in the 1990s this had increased slightly to 35 minutes. It is argued, and supported by research elsewhere, ${ }^{43}$ that travel time is far more important than distance, and that the motor car has allowed people to travel further but has not in other respects changed travel-to-work patterns. Moreover where public transport provision is good, most notably in London, car use has remained at a low level for the journey to work. ${ }^{44}$ Thus, it can be suggested that if access to private motor vehicles had been restricted the time spent travelling to work would have changed little, and the distance over which people travelled would depend primarily on the effectiveness of the public transport system. A good tram or bus network in an urban area can enable a commuter to travel as far in 30-40 minutes as they could by car; however, in smaller settlements with poorer public transport, it is likely that travel-to-work distances would have been significantly less than they are today. Some people, at least, would have had to live much closer to their place of work and the ability to consider trading commuting for residential relocation would have been curtailed. 
Evidence from an analysis of the everyday travel of children aged 10/11 from the 1940s to the present suggests that there has been even less change in personal mobility over the past 50 years (the era during which access to motor vehicles has grown most steeply). For children of this age the main trips undertaken include travel to school, to visit friends for play, to go shopping (both alone and with parents) and outings with other family members. From the 1940s to the present, in urban areas at least, the majority of such journeys are relatively short and do not necessitate use of a car. Thus in Manchester in the 1940s children aged 10/11 travelled on average some 3,500 km in a year, with the average trip distance just $1.3 \mathrm{~km}$. By the start of the $21^{\text {st }}$ century, children of the same age in Manchester travelled further in total (some $4500 \mathrm{~km}$ ) but the average trip distance remained very low at $1.5 \mathrm{~km}$. If we focus on the most common event - the journey to school - in the 1940s in Manchester the mean distance for children aged 10/11 was 1.3 $\mathrm{km}$ and in 2000 the mean distance was $1.4 \mathrm{~km}$. There is thus convincing evidence that despite the widespread use of the car during the second half of the twentieth century, most everyday travel for children living in a city such as Manchester remained short distance. Given that many of these trips were accompanied by an adult (around 80 per cent in both time periods), such short trips were also an important component of the lives of many parents. Data for the much smaller town of Lancaster show very similar trends, though for those living in remoter rural areas there is evidence of a greater increase in everyday travel as more services have become concentrated in towns. ${ }^{45}$ Although car use has obviously increased over the past half century, in 2000 in Manchester almost 65 per cent of all trips by children aged 10/11 were on foot (88 per cent in the 1940s); qualitative evidence suggests that the main reasons for using a car relate to convenience 
and the need to link the trip with other activities, rather than the distance covered for a specific activity such as travel to school. It can thus be argued that the widespread adoption of the motor car has had surprisingly little impact on the everyday mobility of children and their parents and that, if car use had been restricted, patterns of individual everyday mobility would have remained much the same.

For most people longer distance trips (for instance to visit relatives or for leisure) are still relatively rare events and, although access to a car may make such trips more convenient, they were perfectly possible in the period before mass car ownership. Moreover, the mean distance travelled by children for activities such as holidays, social occasions or sporting events has also varied little over the past half century. Thus there is no reason to suggest that even such longer-distance journeys would have been significantly different in a landscape without cars. Perhaps the group that has seen most change in their mobility over the past half century are the relatively elderly. In the 1940s many people in their 60s were considered old and/or infirm and would have travelled little beyond their immediate neighbourhood. Today most people of the same age can travel widely. Indeed several elderly respondents in c2000 suggested that they had more mobility in their 60s than at any other time in their lives. ${ }^{46}$ However, this increased mobility has little to do with the availability of motor transport. Primarily it is a reflection of improved health, increased leisure time following retirement, and surplus income. Some older people do drive but many prefer not to, and discounted fares on trains and buses encourage those over 60 to use public transport. It can be suggested that the elderly have experienced significant 
mobility change over the past century, but that it would have been much the same with or without the motorcar.

Although in terms of personal mobility the impact of the motor car is much less than might be expected, it is likely that restrictions on private car use would have produced more subtle behavioural changes. Thus it is likely that people would undertake fewer trivial journeys, that they would plan their activities more carefully, combining several activities at the same location in one outing rather than popping out repeatedly in the car (especially in rural areas), but that they would be less likely to link together several activities in different locations because complex cross-town journeys would be more difficult. It can be suggested that some women could be more affected than men by such differences. Although women have mostly used cars less than men, the demands of childcare and housekeeping - when combined with paid employment - mean that women often have much more complex journeys than men (who are more likely to travel directly from home to work and back again). As gender differences in access to cars have declined, the car has allowed many women to combine multiple roles more effectively. ${ }^{47}$ It can also be hypothesised that without access to a car travel would be qualitatively different. Thus everyday journeys may have remained much more communal and sociable activities, as people were required to interact on public transport, possibly leading to greater community cohesion. The experience of travel, and the use of travel time, may also have been different for many people if they used less personalised modes of transport than the car. ${ }^{48}$ However, historically, it can also be shown that those able to control their travelling environment have always done so, and thus any impact may have 
been small. ${ }^{49}$ Such behavioural changes, which reflect the ways in which most people managed their mobility in the early twentieth century, would not fundamentally alter overall patterns of mobility today, but life styles, expectations and the experiences of travel that have been built around access to the car would require adjustments.

\section{Urban Life}

Cities can be viewed as organic: their shape, size and structure reflect the lifestyles of their inhabitants and the urban infrastructure. Personal mobility and transport infrastructures both play an important part in shaping the city and in turn reflect urban structure. Spatial expansion and suburbanisation are characteristic of twentieth-century British cities, and it might be assumed that suburban sprawl was dependent on the availability of the motor car, and that in a landscape without cars cities would be both high density and compact to facilitate movement between different activities. However, there is little direct evidence to suggest that the motor car caused suburbanisation or that the lack of access to a car prevents urban sprawl.

Substantial suburbanisation in large British cities began in the second half of the nineteenth century, long before the development of the motor car as a form of mass transport. At that time it occurred largely independently of transport developments: railways mostly followed suburban development, and the affluent who suburbanised could afford the journey into town by existing means (horse-drawn omnibus, tram or private carriage). ${ }^{50}$ A second phase of suburbanisation occurred in the 1920 s and ' 30 s as those on lower incomes moved to newly-built suburban private and social housing 
estates. However, few of the houses built at this time were provided with a garage (or space to build a garage) and the expectation was that people would travel easily from the suburbs to the city by tram or motorbus. ${ }^{51}$ There is evidence to suggest that, especially from the 1950s, the trend of decentralising employment from the city centre or concentrated dockside locations to the urban periphery did encourage those who had access to a car at that time to abandon public transport and use their car to make a more complex cross-city journey,${ }^{52}$ but the motor car did not cause this trend of economic decentralisation (which had much more to do with changing industrial processes, deindustrialisation and land prices), and the car was simply a convenient means of transport at the time. Assuming that in a landscape without cars public transport would have evolved to reflect a new urban structure, then there is no reason why such trends should have been different, though urban development from the 1950s may have been more dense as almost all houses would have been built without garages and parking spaces.

Given that most people seek to minimise travel time and distance, it is likely that other aspects of urban structure may have been different if access to private motor transport had been restricted. In the 1950s, when most people still did not have access to a car, there was much better provision of neighbourhood facilities including shops, schools and social activities. One of the key trends of the late twentieth century has been the closure of local facilities and the concentration of services (especially retailing) in large peripheral complexes. These are usually predicated on the assumption that people have access by car. ${ }^{53}$ If car use had been severely restricted it seems likely that the growth of 
out-of-town shopping complexes would also have been much less, with provision of good public transport to those that were developed, but also the retention of far more neighbourhood facilities. Lack of access to a car would probably also have restricted the extent of counterurbanization that occurred in Britain from the 1960s. ${ }^{54}$ Although some smaller towns with good transport connections would probably still have grown, developments in more remote locations would probably have been curtailed. Overall, it can again be suggested that restricted access to the private motor car would have made much less difference to urban structure and the way in which people lived their everyday life than might at first be anticipated.

In contrast, it can be argued that a landscape without cars would produce a much cleaner urban environment and, potentially, a more healthy urban population. Following the impacts of deindustrialisation (which led to the closure of much potentially polluting industry) and the enforcement of the Clean Air Act in 1956 (which regulated both domestic and industrial smoke emissions in urban areas), the vast majority of air-borne pollutants in towns and cities in Britain have been generated by motor vehicles. For instance, it is estimated that in the UK on average over 50 per cent of nitrogen dioxide and 75 per cent of carbon monoxide is emitted by motor vehicles, ${ }^{55}$ and there is clear evidence of the health effects of living near a main road. ${ }^{56}$ Although some aspects of twentieth-century urban planning have sought to minimise the impacts of cars on pedestrians and cyclists (pedestrianisation, congestion charging, urban speed restrictions), the total impact of such schemes has been limited. ${ }^{57}$ An almost car-free city would have a major impact on the level of air pollution in urban areas, and would certainly make cities 
much more pleasant places in which to live and walk. However, even without private motor transport, an increased number of urban buses could have a significant impact on pollution and, as early as the 1930s, the MoH in Salford was expressing concern about the impact of diesel fumes. ${ }^{58}$ A town full of diesel buses could be just as bad as one congested with cars, and thus arguments to convert public transport to less polluting technology would not have been diminished.

It is more difficult to ascertain the full impact of a town without cars on human health. While removal of cars would have created a cleaner environment, and potentially would have improved human health, the combined effect of other lifestyle factors including diet, exercise, smoking and alcohol consumption arguably all have a much bigger influence on individual health today. ${ }^{59}$ Thus cleaner cities, though pleasant, may not make a substantial difference to individual health. It could also be suggested that in a society without access to the car, more people would walk and cycle in urban areas and that there would thus be added health benefits due to increased exercise. ${ }^{60}$ However, again the evidence is limited. High levels of exercise, including walking and cycling, are more closely correlated with income and lifestyle than with car ownership. For instance, according to 2001 census data the City of Lancaster has a high level of car ownership, but also a high level of walking and cycling as a means of travelling to work. This is reflected in the fact that Lancaster was one of the first six towns in England identified as a 'cycling demonstration town' by the DfT in 2005. In contrast, the city of Liverpool has a very low level of car ownership, but also has low levels of walking and cycling but very high bus use. Thus lack of access to a car does not necessarily mean that people walk and cycle 
more, and beneficial impacts of restricted car access on exercise and health are likely to be highly spatially variable and probably concentrated in those areas which already have a good health record. ${ }^{61}$

\section{Conclusions}

This paper has argued that it is reasonable to imagine a landscape without cars in Britain and, that if access to private motor vehicles had been severely restricted at the start of the twentieth century, the overall impacts on mobility, society and culture would have been much less than might be expected. The paper has not dealt directly with economic implications, and obviously the impact on enterprises directly related to the automobile industry would have been large. However, they would no doubt have developed in other ways and, assuming a good freight transport system, there is no reason why either national economic growth or personal economic security should have been greatly affected. Certainly the transport infrastructure in the country would look rather different, but it is argued that patterns of mobility, work and everyday living would not be significantly different from what they are today, and that there would be only minor differences in urban structure and form. There would probably be the need to plan journeys more carefully, with less spontaneity than is assumed in the $21^{\text {st }}$ century, but this was the case in the 1930s and this did not stop people travelling. Environmental benefits could be substantial, but it is argued that any direct impact on human health is much harder to ascertain. 
A counterfactual argument such as this has many obvious limitations: three points are especially important. First, it assumes that decisions taken within Britain could be made and sustained irrespective of what occurred elsewhere in the world. The emergence of a global economy in the twentieth century (and arguably earlier), ${ }^{62}$ and especially the hegemony of the US economy - itself highly dependent on the motor industry ${ }^{63}$ - makes this a highly unlikely scenario. However, it might also be argued that if the transport industry in Britain (itself still a global power in the early twentieth century) had developed sufficiently strongly, a non-car economy may have become a viable alternative. Second, any counterfactual analysis clearly has to make certain arbitrary decisions about what to change and what to hold constant. The argument in this paper simply assumes that private car use was severely restricted, and that alternative forms of transport developed effectively. A different approach could make much more radical assumptions about changes in the social, economic, political and technological landscape of Britain. For instance, it could be argued that in the absence of the private car there would have been new technological innovations in individualised mass transit, and that it has been the dominance of the car that has inhibited such developments. ${ }^{64}$

While there would have been clear environmental benefits from a restriction on car use, and it is argued that everyday life in Britain would not necessarily have been fundamentally changed, it is important to consider what would also have been lost. Just as there are social and spatial inequalities associated with car use in $21^{\text {st }}$ century Britain, ${ }^{65}$ so too a landscape without cars would have raised issues of social justice with respect to mobility and accessibility. What is interesting, however, is that the groups and places 
most likely to be disadvantaged if car use had been restricted are broadly the same as those that currently experience the most transport poverty. Thus, it can be suggested that it would become more problematic to live in some remote rural areas; that those with the necessity to undertake complex multi-purpose trips (most often women) would experience the most difficulty; that the poor (and the young) may be excluded from some forms of transport; and that those travelling at unsocial hours would have the most difficulty. However, it can also be suggested that such differentials may well have been less than those experienced today as public transport would undoubtedly have been better, and the mobility-privileged would have been most affected by restrictions on private motorised transport. Third, as outlined earlier, social and cultural change is complex and multifaceted. This paper has posited one set of possible outcomes from an assumed set of actions. There may well have been many others.

Although it would certainly have been easier to impose restrictions on motor vehicles in the 1900s than would be the case today, it can be suggested that a landscape without cars (or at least with very few motor vehicles) is still by no means implausible. Many people either choose not to use a car for environmental reasons or cannot afford to run a car (according to the 2001 census 27.4 per cent of households in the UK do not have access to a car); yet most of these will lead full and active lives even with the poor level of public transport provision currently available. Some restrictions on car use have been imposed in many European cities, including London, Oslo and Copenhagen, and there is evidence that an increasing proportion of the population accept that there have to be restrictions placed on car use for environmental reasons. ${ }^{66}$ Although any large-scale 
change in Britain is unlikely to include the banning of car ownership, much greater investment in public transport linked to restrictions on car use do not seem impossible outcomes of current political debates. ${ }^{67}$ This paper has demonstrated that lack of access to a car would not have made a fundamental difference to the ways in which people lived their lives in Britain, and could bring major advantages, even with the technologies available for much of the twentieth century. With the availability of new forms of communication and virtual mobility a landscape without cars would be even easier to manage, though it would also present many challenges. ${ }^{68}$ 


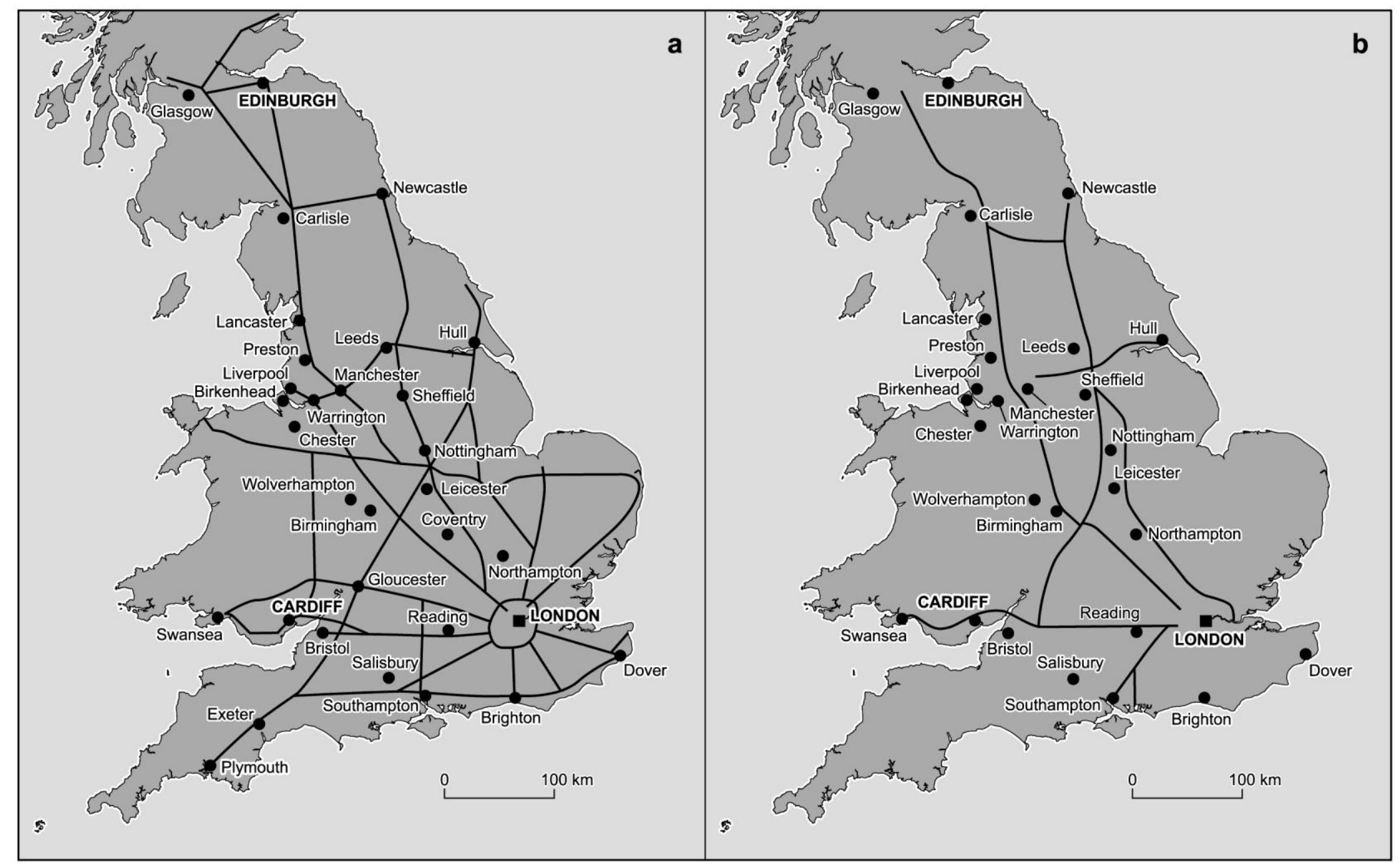

Figure 1: (a) The Institution of Highway Engineers' plan for a network of motorways, published in 1936; (b) The County Surveyors' Society plan for 1000 miles of motorway linking the main industrial centres in the Country, published in 1938. Source: The Motorway Archive: http://www.iht.org/motorway/page1.htm (accessed July 2007) 


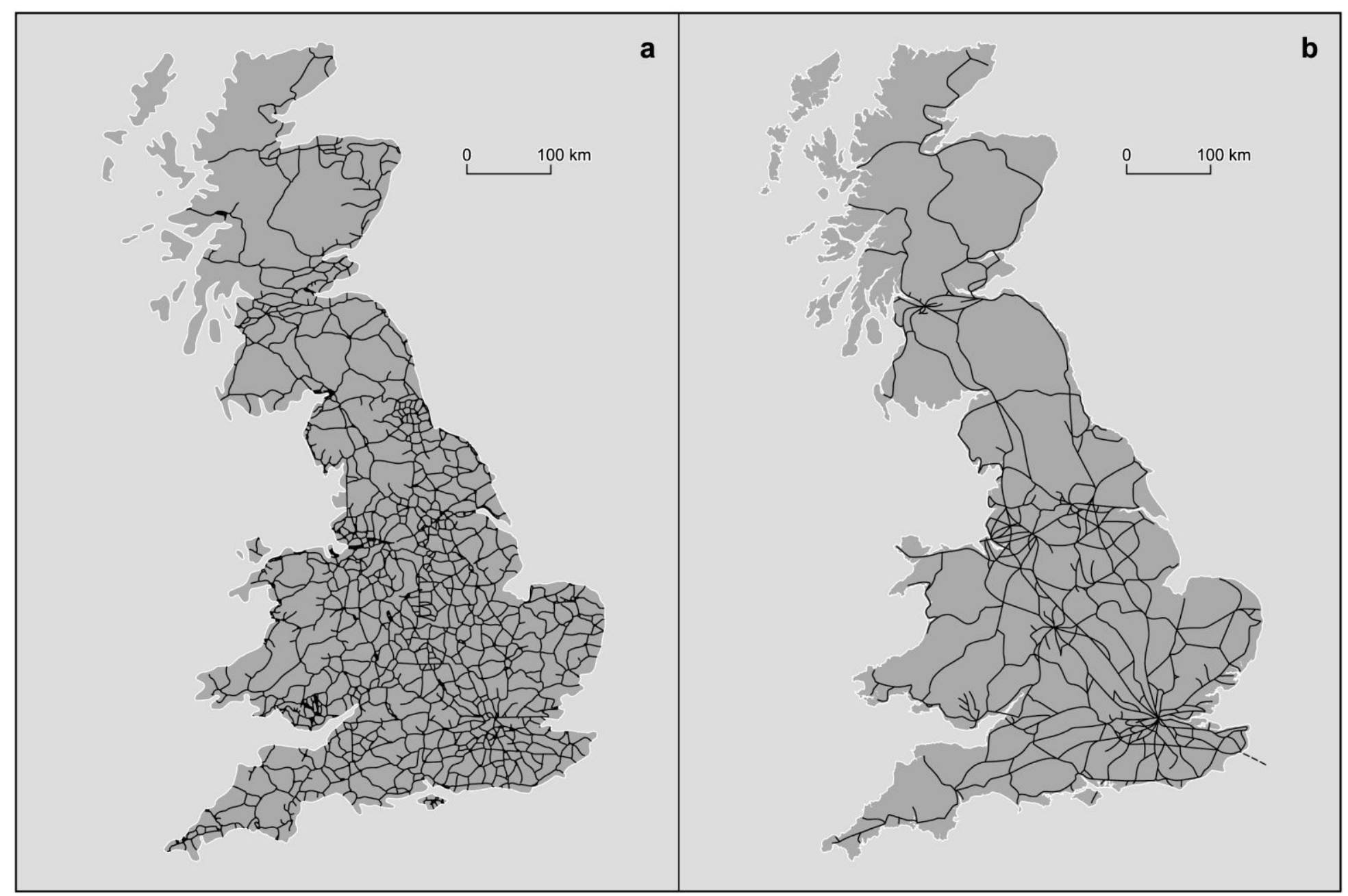

Figure 2: (a) The railway network in Britain c1900 (based on M. Freeman, Transport, in J. Langton and R. Morris, R. (Eds.), Atlas of industrialising Britain, London, 1986, 89); (b) The railway network in Britain c2004 (Source: National rail network website: http://www.nationalrail.co.uk/tocs_maps/maps/network_rail_maps.htm) 


\section{References}

1. J. Adams, The limits to integration: Hypermobility:a challenge to governance, in C. Lyall and J. Tait (Eds), New modes of governance: developing an integrated policy approach to science, technology, risk and the environment, Aldershot, 2005, 123-38; J. Whitelegg (Ed.), Traffic congestion. Is there a way out?, Hawes, 1992; J. Whitelegg, Critical mass: transport, environment and society in the twenty-first century, London, 1997.

2 . Department of Environment, Transport and the Regions, A new deal for transport: better for everyone. The Government White Paper on the future of transport, London, 1998; I. Docherty and J. Shaw (Eds), A new deal for transport? Oxford, 2003; Department for Transport, The future of transport, London, 2004; R. Knowles, J. Shaw, and I. Docherty, Transport Geographies: Mobilities, Flows and Spaces, Oxford, 2008.

3 . Driver and Vehicle Licensing Authority, Annual Report 2007-8, Swansea, 2008.

4. Driver and Vehicle Licensing Authority, Press Release 3, Feb 2003, Swansea, 2003.

5 . M. Sheller and J. Urry, The city and the car, International Journal of Urban and Regional Research 24, 2000, 737-57; J. Beckmann, Automobility - a social problem and theoretical concept, Environment and Planning D: Society and Space 19, 2001, 593-607; J. Urry, The 'system' of automobility', Theory, Culture and Society 21, 2004, 25-39. 
${ }^{6}$. C. Pooley, J. Turnbull and M. Adams, A mobile century? Changes in everyday mobility in Britain in the twentieth century, Aldershot, 2005.

${ }^{7}$. J. Urry, Sociology beyond societies: mobilities for the $21^{\text {st }}$ century, London, 2000; T. Cresswell, On the move: mobility in the modern western world, London, 2006; J. Urry, Mobilities, Cambridge, 2007.

${ }^{8}$. G. Hawthorne, Plausible Worlds: Possibility and Understanding in History and the Social Sciences, Cambridge, 1991; N. Ferguson (Ed), Virtual history: alternatives and counterfactuals, London, 2003; M. Bunzl, Forum essay - counterfactual history: a user's guide, The American Historical Review 109, 2004, 845-58.

${ }^{9}$. R. Cowley (Ed), What if? The world's foremost military historians imagine what might have been, New York, 2004; J. Nielson (Ed), Paths not taken: speculations on American foreign policy and diplomatic history, interests, ideals, and power Westport, Conn, 2000; G. Kornblith, Rethinking the coming of the Civil War: a counterfactual exercise, The Journal of American History 90, 2003, 76-105; J. Huston, Reconstruction as it should have been: an exercise in counterfactual history, Civil War History 51, 2005, 358-63.

${ }^{10}$. R. Fogel, Railroads and American Economic Growth: Essays in Econometric History, Baltimore, 1964; A. Smith, ‘Sport, counterfactual history and rugby's twin codes, The International Journal of the History of Sport 21, 2004, 97-108. 
${ }^{11}$. J. Urry, Global complexity, Cambridge, 2003; M. Featherstone, N. Thrift and J. Urry, Automobilities, London, 2005.

${ }^{12}$. For overviews of the development of motoring in Britain see: W. Plowden, The motor car and politics 1896-1970, London, 1971; H. Perkin, The age of the automobile, London, 1976; K. Richardson, The British motor industry, 1896-1939, London, 1977; T. Barker (Ed), The economic and social effects of the spread of motor vehicles, London, 1987; S. O'Connell, The car in British society: class gender and motoring 1896-1939, Manchester, 1998; P. Merriman, Driving spaces, Oxford, 2007.

13. The Times, Nov 281895 p11 [The Times, Digital Archive 1785-1985:

http://infotrac.london.galegroup.com/itweb/unilanc (accessed July 2007)]

${ }^{14}$. The Times, Nov 281895 p11; Department for Transport, Speed: Know your limits. London, 2004.

15 . The Times, Nov 15 1898, p6; The Times, April 1 1896, p7

${ }^{16}$. The Times, April 21 1900, p15

17. The Times, April 211900 p.15

18 . Driver and Vehicle Licensing Authority, Press Release 3, Feb 2003. Swansea, 2003. 
19 . Department for Transport, Speed: Know your limits. London, 2004.

20 . Driver and Vehicle Licensing Authority, Press Release 3, Feb 2003. Swansea, 2003.

See also C. Emsley, 'Mother, what did policemen do when there weren't any motors?'

The law, the police and the regulation of motor traffic in England, 1900-1939, The

Historical Journal 36, 1993, 357-81

21 . R. Cooter and B. Luckin (Eds), Accidents in history: injuries, fatalities and social relations, Amsterdam, 1997; J. Moran, Crossing the road in Britain, 1931-1976, The Historical Journal 49, 2006, 477-96; B. Luckin and D. Sheen, Defining early automobility: the road traffic accident crisis in Manchester, 1939-45, Cultural and Social History 6, 2009, 211-30

22. The Times, June 15 1929, p7

23. H. Watson, Street Traffic Flow, London, 1933, p375. Also reviewed and quoted in The Times, February 281933 p9

24. Quoted in The Times, March 281934 p9

25 . Department for Transport, Road casualties Great Britain, 2006, London, 2007. 
26. On various aspects of regulation and the impact of cars on pedestrians and traffic see: W. Plowden, The motor car and politics 1896-1970, London, 1971; C. Hass-Klau, The pedestrian and city traffic, London, 1990; D. Engwicht, Towards and eco-city: calming the traffic, Sydney, 1992; H. McClintock (Ed), The bicycle and city traffic, London, 1992; S. Plowden and M. Hillman, Speed control and transport policy, London, 1996.

27 . A similar point was made in a Guardian editorial on July 142008 which compared the small number of highly-publicised deaths in Britain from knife crime with road traffic acidents: http://www.guardian.co.uk/commentisfree/2008/jul/14/transport.

28 . Department for Transport, Transport Statistics (various years): 532,506 killed 19262006

29. For a detailed consideration of these issues see: P. Merriman, Driving Spaces: $a$ cultural historical geography of Britain's M1 motorway, Oxford, 2007.

${ }^{30}$. P. Merriman, Driving spaces, Oxford, 2007 pp24-31.

31. The Motorway Archive: http://www.iht.org/motorway/page1.htm (accessed July 2007)

${ }^{32}$. On the development of the German autobahn network see P. Merriman, Driving spaces, Oxford, 2007 pp31-38. 
33. All material on the development of the road system in NW England from The Motorway Archive: http://www.iht.org/motorway/page1.htm (accessed July 2007)

${ }^{34}$. W. Plowden, The motor car and politics 1896-1970, London; S. O’Connell, The car in British society: class gender and motoring 1896-1939, Manchester, 1998; P. Merriman, Driving spaces, Oxford, 2007.

35 . J. M. Thomson, Motorways in London, London, 1969; J. Jackson, Semi-detached London: Suburban development, life and transport, 1900-39, London, 1973; K. Young and P. Garside, Metropolitan London: politics and urban change 1837-1981, London, 1982; The Motorway Archive.

36 . Manchester Corporation Tramways Department, Annual Report, Manchester, 1926.

37 . C. Pooley and J. Turnbull Commuting, transport and urban form: Manchester and Glasgow in the mid-twentieth century, Urban History, 27, 2000, 360-83.

38 . Greater London Authority, The mayor's transport strategy revision, London, 2004; T. Richardson (Ed.), Interface. Planning and the Big C: Challenging Auto Dependence through Conviction Politics in London, Planning Theory and Practice, 5, 2004, 487-514.

39 . British Railways Board, The reshaping of British railways: report and maps, London, 1963. 
40 . J.A. Patmore, The British railway network in the Beeching era, Economic Geography $41,1965,71-81$

41 . For a fuller discussion of some of these issues see: J Dodgson, Railway costs and closures, Journal of Transport Economics and Policy 18, 1984, 219-35; J. Shaw, W. Walton and J. Farrington, Assessing the potential for a 'railway renaissance' in Great Britain, Geoforum, 34, 2003, 141-56

42 . C. Pooley, J. Turnbull and M. Adams, A mobile century? Changes in everyday mobility in Britain in the twentieth century, Aldershot, 2005.

43. A. Schafer and D. Victor, The past and future of global mobility, Scientific American. October 1997, 36-9.

44 . Greater London Authority, The mayor's transport strategy revision, London, 2004.

45 . Department for Transport, National Travel Survey: 1999/2001 Update, London, 2001.

46 . Pooley, Turnbull and Adams, A mobile century? (2005)

47 . R. Dowling, Cultures of mothering and car use in suburban Sydney: a preliminary investigation, Geoforum 31, 2000, 345-53. 
${ }^{48}$. M. Featherstone, N. Thrift and J. Urry, Automobilities, London, 2005; G. Lyons and J. Urry, Travel-time use in the information age, Transportation Research A, 39, 2005, 25776; D. Bissell, Animating suspension: waiting for mobilities, Mobilities, 2, 2007, 277-98; D. Bissell, Visualising everyday geographies: practice of vision through travel-time, Transactions of the Institute of British Geographers 34, 2009, 42-60.

49 . C. Pooley, J. Turnbull and M. Adams, The impact of new transport technologies on intra-urban mobility: a view from the past, Environment and Planning A 38, 2006, 25367.

50 . H.J. Dyos and D. Aldcroft, British transport: an economic survey from the seventeenth century to the twentieth, Leicester, 1969; J. Jackson, Semi-detached London: Suburban development, life and transport, 1900-39, London, 1973.

51 . J. Burnett, A social history of housing, 1815-1970, Newton Abbot, 1978.

52 . C. Pooley and J. Turnbull, Commuting, transport and urban form: Manchester and Glasgow in the mid-twentieth century, Urban History 27, 2000, 360-83.

53 . N. Wrigley and M. Lowe, Reading retail: a geographical perspective on retailing and consumption spaces, London, 2002. 
${ }^{54}$. A. Champion, Counterurbanization: the changing pace and nature of population deconcentration, London, 1989.

55. UK National Air Quality Archive: http://www.airquality.co.uk/archive/index.php (accessed July 2007)

${ }^{56}$. G. Hoek, B. Brunekreef, S. Goldbohm, P. Fischer and P. van den Brandt, Association between mortality and indicators of traffic-related air pollution in the Netherlands: a cohort study, The Lancet 360: 9341, 2002, 1203-1209; J. Kim, S. Smorodinsky, M. Lipset, B. Singer, A. Hodgson and B. Ostro, Traffic-related air pollution near busy main roads: the East Bay children's respiratory health study, American Journal of Respiratory and Critical Care Medicine 170, 2004, 520-6.

57 . C. Hass-Klau, The pedestrian and city traffic, London, 1990; D. Engwicht, Towards and eco-city: calming the traffic, Sydney, 1992; H. McClintock (Ed), The bicycle and city traffic, London, 1992; S. Plowden and M. Hillman, Speed control and transport policy, London, 1996; T. Richardson (Ed.), Interface. Planning and the Big C: Challenging Auto Dependence through Conviction Politics in London, Planning Theory and Practice, 5, 2004, 487-514.

58 . Annual Report of the Medical Officer of Health, Salford, 1936 
${ }^{59}$. R. Hancox, B. Milne and R. Poulton, Association between child and adolescent television viewing and adult health: a longitudinal birth cohort study, The Lancet, 364: 9430, 2004, 257-62; M. Hassan, A. Joshi, S. Madhavan and M. Amonkar, Obesity and health-related quality of life: a cross-sectional analysis of the US population, International Journal of Obesity, 27.10, 2003, 1227-32.

${ }^{60}$. P. Rosen, P. Cox, D. Horton, Cycling and Society, Aldershot, 2007; D. Ogilvie, C. Foster, H. Rothnie, Interventions to promote walking: systematic review British Medical Journal 334, 2007, 1204-7.

${ }^{61}$. R. Mackett, Policies to attract drivers out of their cars for short trips, Transport Policy 8, 2001, 295-306; R. Mackett, Why do people use their cars for short trips?, Transportation 30, 2003, 329-49.

${ }^{62}$. A. Hopkins (Ed), Globalization in world history, London, 2002; A. Macgillivray, A brief history of globalization: the untold story of our incredible shrinking planet, London, 2006.

${ }^{63}$. M. Rupert, Producing hegemony: the politics of mass production and American global power, Cambridge, 1995.

${ }^{64}$. B. Latour, Aramis, or the love of technology, Cambridge, Mass., 1996 
${ }^{65}$. J. Farrington and C. Farrington, Rural accesibility, social inclusion and social justice: towards conceptualsiation, Journal of Transport Geography 13, 2005, 1-12; D. Gray, Rural transport and social exclusion: developing a rural transport typology, Built Environment 3, 2004, 172-81; J. Hine and F. Mitchell, Transport disadvantage and social exclusion: exclusionary mechansisms in transport, Aldershot, 2003.

${ }^{66}$. T. Richardson (Ed.), Interface. Planning and the Big C: Challenging Auto Dependence through Conviction Politics in London, Planning Theory and Practice, 5, 2004, 487-514; S. Glaister, D. Graham, W. Wong, R. Noland and H.Bell, An evaluation of national road user charging in England and Wales, Transportation Research, Part A: Policy and Practice, 39, 2005, 632-50; J. Eliasson, and L. Mattsson, Equity effects of congestion pricing: quantitative methodology and a case study for Stockholm, Transportation Research, Part A: Policy and Practice 40, 2006, 602-20.

67. On the current debate about high-speed rail in Britain see The Guardian August $5^{\text {th }}$ and $6^{\text {th }}$ 2009: http://www.guardian.co.uk/world/2009/aug/05/highspeed-rail-travel-ukscnf; http://www.guardian.co.uk/uk/2009/aug/06/questions-london-birmingham-rail-link (accessed August 2009). Also K. Dennis and J. Urry, After the car, Cambridge, 2009-0813.

68 . J. Larsen, J.Urry and K. Axhausen, Mobilities, networks, geographies, Aldershot, 2006; J. Urry and K. Dennis, The digital nexus of post-automobility, on-line paper, 
Department of Sociology, Lancaster University, 2007; J. Urry, Climate change, travel and complex futures, British Journal of Sociology 59, 2008, 261-79. 